\title{
Research of Teaching Model for Public Security Information Management Course based on Network Learning Community
}

\author{
Hu Liang \\ Department of humanities and management \\ JiangXi Police College \\ NanChang, China \\ huliang_thu@163.com \\ Zhu YuChi \\ Department of humanities and management \\ JiangXi Police College \\ NanChang, China
}

\author{
Wen Jin \\ Department of humanities and management \\ JiangXi Police College \\ NanChang, China \\ Xu Jing \\ Department of humanities and management \\ JiangXi Police College \\ NanChang, China
}

\begin{abstract}
In order to explore the effectiveness of learning community learning model, this paper takes the public security information management course as an example to study the design of classroom interaction, learning evaluation criteria and the construction of learning community. The research results show that the learning community learning model can help students to learn and promote the teaching of public security information management.
\end{abstract}

Keywords_public securit; information management; course; network learning community

\section{INTRODUCTION}

Public security information management curriculum is under the background of global informatization, for training in line with public security informationization requirements of talents and set a new course, management science and information science two branch discipline development of is subordinate branch curriculum information management science and its theoretical basis is the result of management science and Information Science[1].

Public security colleges set up public security information management courses, students can not only learn to use computer language to express their thinking, grasp the basic ideas and methods of information system design, the use of computer to solve the practical problems, but also improve the students' abilities of analyzing problems, problem solving ability, is conducive to the cultivation of the ability of logical thinking and rigorous scientific style, cultivate a group has both public security business knowledge and skills, and can play a personnel information specialty in the course of public security information[2]. But since, due to public security information management courses grammar boring, rigorous, students can not quickly adapt to the information system to solve the problem of mode of thinking, and the course general opened in the second semester, student based curriculum tasks are relatively heavy, assigned to a particular course of time and effort is rather limited. Therefore, we can say it is the public security management is difficult to start a foundation course[3].

Learning community is a composed of learners and student learning communities, have a common goal, in a supporting environment to learn together, share a variety of learning resources, through mutual dialogue and communication, share each other's feelings, experiences and ideas, work together to complete a certain learning tasks, in common activities have gradually formed mutual influence and mutual promotion of interpersonal relationship, and the group has a strong identity and sense of belonging, promote learning comprehensive growth.

Since the 20th century, with the development of information technology and learning theory, the world schools and educational reform wave high one billow, in the process of the reform of the "school is a community of learners", "school is a community of learning" teaching concept, many studies show clear construction of learning community plays an important role in professional development, of which the most influential is proposed by Brown learners and thinkers community[4][5]. Learning community theory holds that the effective teaching began in the learners into the teaching environment of existing knowledge, aims to help the students to combine their prior knowledge and the learning task, teachers should understand each student know what, and what they are interested in, what to do, what you want to do, so between the learners and the student teacher professional community and learning community, learning together, share a variety of learning resources, through mutual dialogue, exchange and communication together to complete certain learning tasks[6][7][8][9].

Therefore, in teaching introduced learning community, can promote teachers and students to share their thinking, experience and knowledge, exchange each other's feelings, 
experiences and ideas, enrich the teaching content, to obtain new findings, so as to achieve shared together, teachers and common development, formation of ordered strong group dynamic, members of the community can be to explore and solve problems with their collective wisdom and knowledge, individual knowledge learning has also been growing[10][11][12]. This topic will to public security information management courses, for example, from the construction of knowledge and construction of learning community, classroom interaction design, organization and process monitoring, learning evaluation standard launches the research, to fill the blank of this kind of teaching reform of the course, to cultivate a adapt to the current needs of the community public security innovative talents of information and education to provide a reference for the reform[13][14].

\section{RESEARCH STATUS OF LEARNING COMMUNITY}

Since 1970s, the science of learning has been developing rapidly, and many educators begin to study it from the aspects of social and cultural characteristics[15]. In 1995, Boyer, a famous educationist, first proposed the concept of learning community, he believes that "learning community is all due to the mission of the community and towards a common vision with learning organization, the community of people sharing an interest in learning, work together to find the leading to the knowledge of the journey and understand the workings of the world, towards the education of the same target interaction and participation. Subsequently, the learning community is widely studied, on the one hand, as a teacher professional development model, on the other hand, as a kind of learning mode.

Since Boyer and I put forward the concept of learning community, various countries have launched a research based on the topic[16]. In 1989, University of Toronto, created a computer supported intentional learning environment, with the help of the network system to form a learning community in the classroom. In 1994, Northwestern University and University of Illinois jointly developed the collaborative visualizaton project, the use of network and multimedia technology, experts in related fields of tools and methods to construct the distributed multimedia learning environment of middle school science learning, between the experts, teachers and students and build a community of practice, so that students can participate in the real scientific practice. In 2002, the United Kingdom in a project related to young people to create a network learning community, the purpose is to promote the exchange of experience and cooperation within the educational system. In 2005, Professor Charlotte Gunavadna put forward the best or the most important method of network teaching is to establish a network learning community.

The concept of learning community was introduced into China in the late 1990s, which is widely studied[17]. In 1999, the Nangang Harbin District Education Bureau began to explore the theory and practice of school management with the learning community theory, and made great achievements. Tsinghua University Dr. Zhang Jianwei from the academic support, cognitive support and interpersonal support of the three layers of the network learning community has been studied, and the concept of learning community and function. In 2006, China's future research will education branch, and the future research institute jointly organized the Chinese Learning Community Research Institute, hire Sato professor as chief advisor, dedicated to the study of learning community. In 2009, Shao Jie, Ningbo University, conducted a research and practices of classroom teaching mode based on teach community -- a case study of program design course. In 2010, Chen Yao argued that the classroom should be a learning community that highlights the characteristics of learning society, autonomy and life. But the classroom is a kind of limited learning community under the school education system." In 2010, Zhao Ling proposed the framework of College English teaching mode based on network learning community. In 2011, Guo Yongzhi conducted the design of College English teaching based on the learning community theory.

In order to understand the application of learning community in College English teaching, this study conducted a questionnaire survey in 3 universities[18][19]. A total of 100 questionnaires were distributed, and $83 \%$ questionnaires were valid. The results of the survey shows that $66 \%$ of teachers have not heard of the concept of community learning, $23 \%$ of the teachers heard but it is not clear what is the learning community, but $78 \%$ of teachers' willingness to understand, learn and try to use the learning community. In the survey of students, 3\% of the students do not want to accept learning community learning mode; $16 \%$ of the students think learning community learning mode is not to their learning bring a positive impact; $81 \%$ of the students think traditional learning mode should be replaced, they are willing to accept the new learning community learning mode.

\section{CONSTRUCTION OF NETWORK LEARNING COMMUNITY}

Students relying on network teaching platform, in compliance with community norms under the premise, according to the teachers to provide information and learning resources, between the text communication, voice conversation and interactive video a variety of ways communicate and in the process of gradually formed a strong identity, with a sense of trust and a sense of belonging, finally realizing information share and members and grow together. The model of the network learning community is shown in Fig.1:

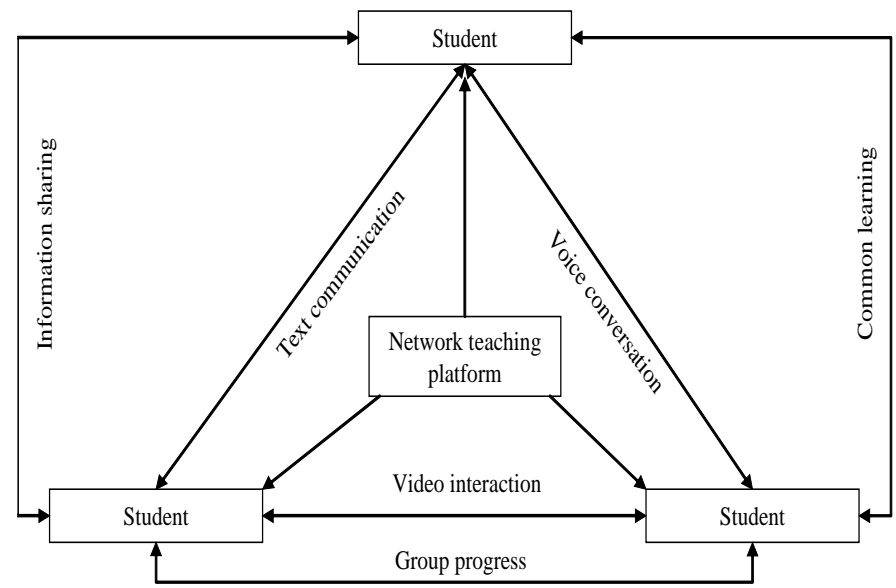

Fig. 1. Network learning community model of public security information management course 


\section{QUESTIONNAIRE DESIGN AND DATA STATISTICS}

In order to understand the learning community teaching situation, this paper designed a questionnaire, so that the students of the experimental class to evaluate the public security information management course. For each question, this paper designs 5 options (Totally agree, General agree, Basic agree, Disagree, Totally disagree), the results are shown in Table 1.

TABLE I. QUESTIONNAIRE SURVEY OF NETWORK LEARNING COMMUNITY MODEL

\begin{tabular}{cccccc}
\hline & $\begin{array}{c}\text { Totally } \\
\text { agree }\end{array}$ & $\begin{array}{c}\text { General } \\
\text { agree }\end{array}$ & $\begin{array}{c}\text { Basic } \\
\text { agree }\end{array}$ & Disagree & $\begin{array}{c}\text { Totally } \\
\text { disagree }\end{array}$ \\
\hline $\begin{array}{c}\text { Improves } \\
\text { students' learning } \\
\text { environment }\end{array}$ & 0.912 & 0.059 & 0.029 & 0 & 0 \\
$\begin{array}{c}\text { Exert students' } \\
\text { subjective } \\
\text { performance }\end{array}$ & 0.941 & 0.059 & 0 & 0 & 0 \\
$\begin{array}{c}\text { Enhance the role } \\
\text { of Teachers }\end{array}$ & 0.838 & 0.059 & 0.044 & 0.044 & 0.015 \\
$\begin{array}{c}\text { Improve student } \\
\text { achievement }\end{array}$ & 0.882 & 0.074 & 0.044 & 0 & 0 \\
$\begin{array}{c}\text { Conducive to } \\
\text { language learning }\end{array}$ & 0.868 & 0.103 & 0.029 & 0 & 0 \\
$\begin{array}{c}\text { Enhance the } \\
\text { ability to use } \\
\text { learning tools }\end{array}$ & 0.882 & 0.059 & 0.059 & 0 & 0 \\
$\begin{array}{c}\text { Improving } \\
\text { autonomous } \\
\text { learning ability }\end{array}$ & 0.750 & 0.118 & 0.088 & 0.044 & 0 \\
$\begin{array}{c}\text { Learning effect is } \\
\text { very good }\end{array}$ & 0.809 & 0.103 & 0.059 & 0.029 & 0 \\
\hline
\end{tabular}

From the Table 1 shows that most students like to be close to the actual situation in life, in the guidance of teachers and help, in the interaction with the students, in the space to play their own personality to learn and grow. Most of the students like to learn the community learning model, and think that it is scientific and effective.

\section{ANALYSIS OF STUDENT ACHIEVEMENT}

In order to better understand the impact of learning community learning mode on the public security information management course, this paper tests the students in the test class and the control class, and then analyzes the students' scores.

The test class and the control class achievement description statistics and independent sample t test statistic analysis results are shown in Table 2 shows that the experimental class and the control class subjects with homogeneity, there is no statistically significant difference $(\mathrm{P}>0.05)$.
TABLE II. TEST CLASS AND CONTROL CLASS PERFORMANCE OF THE DIFFERENCE TEST

\begin{tabular}{ccccc}
\hline & N & M & SD & t \\
\hline Test class & 68 & 72.42 & 9.29 & 1.42 \\
Control class & 65 & 70.12 & 9.39 & \\
\hline
\end{tabular}

The test class for learning community learning in paired samples t-test are shown in Table 3, before and after the experiment, the control class learning achievement changes showed significant difference $(\mathrm{P}<0.01)$, suggesting that the experimental class teaching mode of community learning performance is obviously improved, the common learning mode is effective teaching mode before and after the results.

TABLE III. DIFFERENCES OF SCORES IN THE TEST CLASS BEFORE AND AFTER THE TEACHING OF LEARNING COMMUNITY

\begin{tabular}{cccc}
\hline & M & SD & t \\
\hline $\begin{array}{c}\text { Not using network learning } \\
\text { community model }\end{array}$ & 72.42 & 9.29 & -4.21 \\
$\begin{array}{c}\text { Using network learning community } \\
\text { model }\end{array}$ & 78.30 & 6.87 & \\
\hline
\end{tabular}

The test class and the control class control after learning achievement of descriptive statistics and independent sample $t$ test statistics analysis results are shown in Table 4 shows, different learning modes of learning in the experimental class and the control class is not homogeneous, there is a statistically significant difference $(\mathrm{P}<0.01)$. The average score of the experimental class was significantly higher than that of the control class. This shows that the community learning model has a certain effect on the students' learning.

TABLE IV. DIFFERENCE OF THE SCORES OF THE TEST CLASS AND THE CONTROL CLASS

\begin{tabular}{ccccc}
\hline & $\mathbf{N}$ & $\mathbf{M}$ & SD & t \\
\hline Test class & 68 & 78.30 & 6.87 & 5.02 \\
Control class & 65 & 72.43 & 6.61 & \\
\hline
\end{tabular}

\section{DISCUSSION AND FUTURE WORK}

Before the teaching practice of learning community, the average score of the experimental class and the control class was slightly different, but the difference was not significant. According to the results of the control before the analysis, the test is homogeneous, there is no significant difference $(\mathrm{P}>0.05)$ which is consistent with the experimental conditions. In after a year of study, the experimental class learning achievement than prior to the implementation of the control has been significantly improved, the average score increased from 72.43 to 78.30, while the control class grades did not change significantly, average scores divided by are 70.12 ascend to 72.43 points. Implementation of learning community learning teaching model in the experimental class and non implementation of the mode of the control group compared, academic performance significantly increased $(\mathrm{P}<0.01)$ 
indicating that learning community learning to promote students' learning, and achieved good results.

The public security information management majors as the object of study, the teaching mode based on mutual learning, to public security information management curriculum reform, to enable students to actively participate in, to stimulate students interest in learning, students in cooperative learning in the process of understanding, knowledge, improve the analysis of issues and problem solving ability, teaching ideas with the promotion of universal values can be applied to many teaching and research methods for other teaching modes, the researchers also has a certain reference value.

This study shows that learning community learning model to achieve the transition "from teaching to learning", breaking the traditional monotonous teaching environment, create a new harmonious, active learning atmosphere; to stimulate students interest in learning, improve student achievement, advantageously promote teaching; cultivate the students sense of participation, and help students to build up self-confidence, make students through communication and interaction between the development of language skills, and to develop the autonomous learning ability and the ability of social communication.

\section{ACKNOWLEDGMENT}

This author's work is supported by JiangXi Research on teaching reform of higher education (JXJG-14-19-1, JXJG-1519-3), JiangXi Science and technology research project of Education Department (GJJ151193), JiangXi Social Science Planning Projects during the 12th Five-Year Plan (14TQ05) and JiangXi Police College Scientific Research Project(2014QN001).

\section{REFERENCES}

[1] Gao Liming. Study on College Teachers' curriculum design ability [J]. Peking University education review, 2004: 102-107. (In Chinese)
[2] Nan XuGuang. Analysis of task driven teaching mode based on network learning community [J]. Modern educational technology, 2009, (12): 6871. (In Chinese)

[3] Feng Li. Environment of informal learning social software construction [D]. Chongqing: Southwestern University, 2009. (In Chinese)

[4] Yang HongGang. Research on the construction of network learning community [J]. Modern Educational Technology, 2010, (5): 93-96. (In Chinese)

[5] Chen Y. Research on the reform of community policing in China from the perspective of New Public Administration[J]. Journal of Railway Police College, 2014(04). (In Chinese)

[6] Wang Dong. Study on the realization mechanism of knowledge sharing in virtual academic community [D]. Changchun: Jilin University, 2010. (In Chinese)

[7] Wang YanMei. Virtual community interactive multi perspective comparison and value analysis [J]. Library Research, 2010, (11): 23-28. (In Chinese)

[8] Zhou L, Wang Q. Research on the professional setting and personne training of Foreign Police[J]. Journal of Yunnan Police Officer College, 2013(04). (In Chinese)

[9] Chen Z. Related research and theory on the important influence of community policing[J]. Journal of Liaoning Police College, 2003(02). (In Chinese)

[10] Zhao GuoDong. Study on student satisfaction and its influencing factors of blended learning [J]. Chinese distance education, 2010, (6): 32-38. (In Chinese)

[11] Xiang D. Foreign Police[M]. Beijing: Chinese People's Public Security University press, 2004:1. (In Chinese)

[12] Zhao GuoDong. The use of E-Learning to create a new teaching system of research universities [J]. Modern educational technology, 2010, (8): 5-10. (In Chinese)

[13] Wang J. Community security group[J]. Journal of Chinese People's Public Security University, 2002(2):84. (In Chinese)

[14] WangJ, Li X. On the problems and Countermeasures of community policing $[\mathrm{J}]$. Journal of Zhejiang Police College, 2005, (6). (In Chinese)

[15] Lv Y. Reflections on the cultivation of international police talents[J]. Journal of Hubei University of Police, 2008(2):119-122. (In Chinese)

[16] Xin Z. Foreign police course[M]. Beijing: Chinese People's Public Security University press, 2005:1. (In Chinese)

[17] Shi X. On the training of police personnel in Public Security Colleges[J]. Journal of Railway Police College, 2014(03). (In Chinese)

[18] Jiang X. On community policing construction in the context of urban community self governance[J]. Journal of Shanghai Police College, 2013(05); (In Chinese)

[19] $\mathrm{Wu} \mathrm{Y}$. Research on the construction of the normal long-term mechanism of community policing[J]. Policing Studies, 2010(03). (In Chinese) 